\title{
A LÍNGUA AKWẼ E A LÍNGUA PORTUGUESA EM CONTATO: AMEAÇA OU ENRIQUECIMENTO LINGUÍSTICO?
}

\author{
Sílvia Letícia Gomes da Silva Xerente ${ }^{1}$
}

\section{RESUMO}

O presente artigo visa apresentar a situação sociolinguística do povo Akwẽ, discutir a situação de contato linguístico que existe entre esta língua e o português e, dessa forma, contribuir para a vitalização dessa língua e dessa cultura. Assim, acredito que os resultados, aqui apresentados, poderão levar a comunidade a refletir acerca da valorização de sua língua e de seus costumes, garantindo, então, a sustentabilidade dos conhecimentos desse povo. Dessa forma, o objetivo desse artigo é, além de apresentar a situação sociolinguística do povo Akwẽ, propor ações que contribuam com a sustentabilidade linguística desse povo.

PALAVRAS CHAVE: Língua Akwẽ. Valorização. Contato linguístico.

\section{ABSTRACT}

This article aims to present the sociolinguistic situation of the Akwẽ people, to discuss the situation of the linguistic contact that exists between this language and Portuguese and, in this way, to contribute to the vitalisation of that language and culture. Thus, I believe that the results presented here may lead the community to reflect on the value of their language and customs, guaranteeing the sustainability of their knowledge. So, the purpose of this article is, besides presenting the sociolinguistic situation of the Akwẽ people, propose actions that contribute to the linguistic sustainability of these people.

KEYWORDS: Akwẽ language. Appreciation. Linguistic contact.

1 Licenciada no Curso de "Educação Intercultural" (Ciências da Linguagem) pela Universidade Federal de Goiás e em Pedagogia pela Universidade Federal do Tocantins (UFT). Pós-graduada em Gestão Escolar. Professora do ensino fundamental, na Escola Municipal Professor Constantino Pedro de Castro, em Tocantínia; e da EJA, na Escola Estadual Indígena Sakruiwe. Pesquisadora da Ação "Saberes Indígenas na Escola", Rede UFG/UFT/ UFMA. Tocantínia, TO, Brasil. E-mail: silviaketi_gsx@hotmail.com. 


\section{Apresentação}

O presente artigo traz uma reflexão sobre a situação sociolingüística do povo indígena Xerente. Para fundamentar tal artigo, foi desenvolvida uma pesquisa em diferentes aldeias das Terras indígenas Xerente e Funil. Assim, traz como eixos norteadores a sustentabilidade cultural, econômica, linguística e a diversidade, que são bases que sustentam os trabalhos desenvolvidos pelos professores indígenas nas comunidades de cada povo, representado na Ação "Saberes Indígenas na Escola".

Durante a pesquisa, foram feitas entrevistas com anciãos, bem como membros da comunidade de diferentes faixas etárias, para termos um levantamento da realidade linguística do povo Akwẽ. Além disso, apliquei 207 questionários para crianças, jovens e adultos, de diferentes aldeias. Dentre as questões que investiguei nesses questionários, estão os espaços em que está sendo usada a língua Akwẽ e a língua portuguesa, qual faixa etária faz mais uso da língua portuguesa, se o uso dessa língua pode prejudicar a língua materna ou não.

Busquei, também, saber como está sendo vivenciado pelos Akwẽ, esse contexto de contato entre falantes de línguas diferentes e que sentimento eles têm pela sua língua materna.

A primeira parte desse trabalho traz uma reflexão sobre a organização social desse povo, pinturas clânicas e aldeias existentes, hoje, dentro das reservas Xerente e Funil. Na segunda parte, é feito um breve histórico do contato entre falantes da língua Akwẽ e da língua portuguesa, bem como os conflitos que existem nesse contexto. $\mathrm{Na}$ terceira parte, é apresentado o diagnóstico sociolinguístico do povo Akwẽ, bem como os contextos de uso da língua Akwẽ pelos seus falantes.

Durante a pesquisa, fiz várias leituras que indicam que há no Brasil grande ameaça de extinção de línguas indígenas emanada por inúmeros fatores. Entendo, assim, que essa pesquisa é de extrema relevância na tentativa de abrir e buscar caminhos para o processo de afirmação da língua indígena Akwẽ para que a mesma não desapareça.

Além disso, os resultados dessa pesquisa, aqui apresentados, possibilitarão o enriquecimento linguístico dos Akwẽ, na medida em que o trabalho discutirá os empréstimos linguísticos, suas vantagens e desvantagens, e o que poderá mobilizar a comunidade na criação 
de novas palavras que venham substituir alguns empréstimos desnecessários.

Considera-se, então, que a ocorrência dos empréstimos linguísticos é algo inevitável na situação atual do povo Akwẽ, pois compartilhamos o mesmo território com os falantes da língua portuguesa, e também fazemos uso dessa língua para fins educacionais, políticos, econômicos etc. Dessa forma, esse artigo é de suma importância, pois contribuirá para uma reflexão sobre a criação de políticas linguísticas de fortalecimento dessa língua, além de servir para o nosso povo Xerente como material de pesquisa, bem como meio de reflexão sobre as mudanças que ocorreram e podem ocorrer na língua Akwẽ.

\section{Uma reflexão geral sobre o povo Xerente}

\subsection{Histórico do povo Xerente}

Nessa primeira parte do estudo, trarei um breve histórico do povo Xerente, explicitando como foi o contato dos mesmos com a sociedade não indígena, ao longo dos anos.

$\mathrm{O}$ povo Xerente se autodenomina Akwẽ, e fala a língua Akwẽ, que pertence ao tronco linguístico Macro-Jê. Segundo os dados da Fundação Nacional do Índio (2010), sua população chega a 3.200 pessoas, que vivem em 65 aldeias, localizadas na cidade de Tocantínia, na região central do estado de Tocantins. Seu território é dividido em Terra Indígena Xerente e Terra Indígena Funil, conforme veremos no mapa abaixo (Figura 1): 
Figura 1 - Mapa de localização do Território Akwē Xerente.

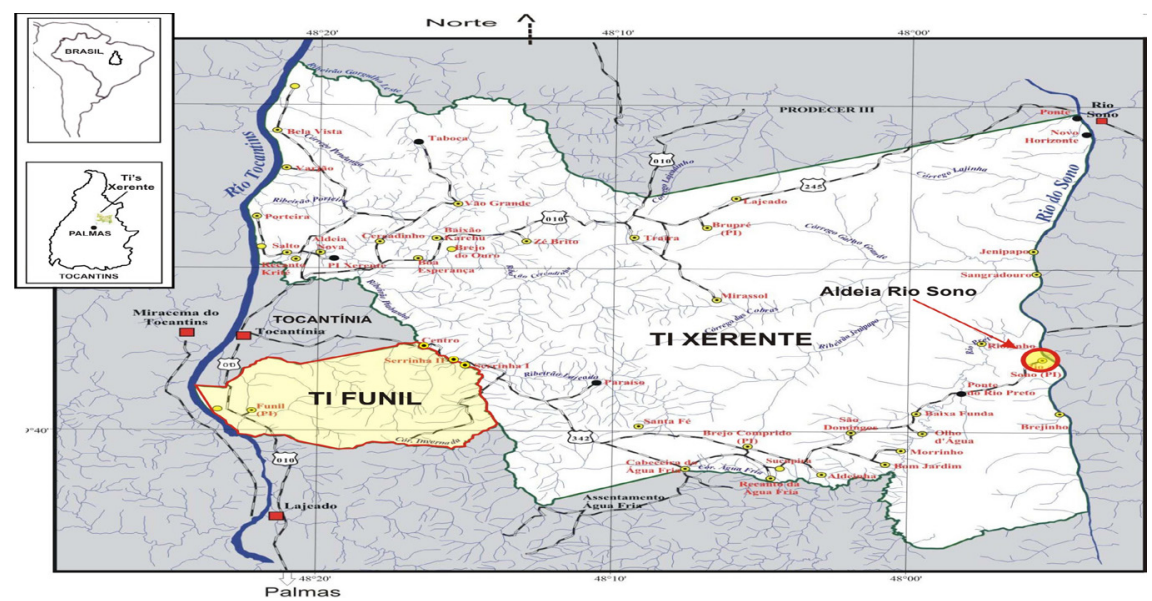

Fonte: OPAN E GERA/UFMT, diagnóstico Etno-Ambiental, junho de 2000, apud Schroeder (2006).

As 65 aldeias são localizadas em cinco Regiões, sendo elas Xerente, Brupre, Brejo Comprido, Rio Sono e Funil.

Segundo Paula (1999), nós Xerente já temos cerca de 250 anos de contato com a comunidade não indígena, porém, apesar disso, não perdemos nossos costumes, nossa língua e nossa identidade social.

Assim, hoje ainda são praticadas pelos Xerente a caça e a pesca, apesar de haver dentro da reserva uma quantidade significativa de servidores públicos que possuem atividades e hábitos alimentares diferentes dos demais, por causa da sua rotina de trabalho pautada na lógica não indígena, que nos traz cada dia um novo modo de vida. As roças tradicionais também ainda são cultivadas para garantir a alimentação do povo, porém, já há pesquisas que apontam que as famílias Xerente estão consumindo mais produtos industrializados. Conforme afirma Xerente, "é muito comum essa relação comercial entre os Akwẽ e os não indígenas das cidades vizinhas, principalmente na cidade de Tocantínia. Nessa relação comercial a participação dos indígenas na compra de produtos industrializados é expressiva (...)".

São confeccionados também artesanato em capim dourado pelas mulheres. Dentre as peças, geralmente são feitos brincos, pulseiras, bolsas, mandalas, porta moedas, dentre outras. Esses artesanatos geralmente são feitos para a comercialização na cidade de Tocantínia, para contribuir com a renda das famílias. Há compradores 
que entram nas aldeias e adquirem os mesmos por preços baixos, o que faz com que os indígenas não obtenham um valor equivalente ao valor real do produto.

Há outros artesanatos confeccionados pelas mulheres que são para o uso em festas tradicionais e rituais como os sutiãs, saias, colares, esteiras, dentre outros. Já os homens fazem lanças, bordunas, cofos, arcos e flechas, cocares, tanto para o próprio uso, quanto para comercialização.

Quanto às fontes de renda, hoje há, dentro das aldeias, além dos funcionários da FUNAI, Estado e prefeitura, muitos que recebem bolsa família, bolsas de estudo, pensões alimentícias e aposentadorias. Há também os funcionários da saúde, e os funcionários do IBAMA, que trabalham com a prevenção de queimadas dentro da Reserva Akwẽ.

Apesar dos dados apresentados acima, o meu povo Akwẽ ainda possui uma tradição cultural muito forte, praticamos os nossos rituais, valorizamos a nossa língua materna e passamos os nossos conhecimentos de geração a geração.

Porém, alguns empreendimentos, como a Usina Lajeado, geraram impactos que incidiram simultaneamente sobre atividades de pesca e agricultura praticadas pelos Xerente, o que trouxe interferências na nossa dieta alimentar. No entanto, esses impactos não atingem tão somente as condições de reprodução da vida material, hábitos alimentares e saúde física dos Akwě, mas também o nosso mundo mental, considerando que nossos próprios nomes encontram-se muitas vezes associados àquilo que, ao olhar dos não índios, se apresenta estritamente como "recursos naturais".

Ainda nessa mesma linha de pensamento, no próximo tópico, trataremos da organização social do povo Akwẽ, para entendermos melhor a relação disso com o respeito existente entre os pertencentes desse povo e a importância do tema dessa pesquisa.

\subsection{A Organização social do povo Akwẽ}

A organização social do povo Akwẽ está centrada na divisão entre as duas metades, que representam as divisões clânicas, são elas: Doi e Wahirê. A metade Doi inclui os clãs kuzâptekwa, Kbazitdkwa e Kritoitdekwa; já a metade Wahirê, inclue os clãs Krozake, Kreprehi e Wahirê. As duas metades se respeitam e não desobedecem às obrigações que cada uma tem que cumprir. Essas obrigações estão 
relacionadas a vários rituais da nossa cultura, como Damrõze (casamento), Dasĩpê (nomeação), Kupre (pós-funeral), dentre outros rituais. Neles, cada clã sabe da sua responsabilidade e assume, garantindo assim que os nossos saberes não se percam com o passar dos anos, apesar de termos o constante contato com a sociedade não indígena, e que esses conhecimentos continuem fortes nas aldeias, conforme afirma Xerente (2012), "a população Akwẽ ainda preserva sua língua materna influenciada por diversos interesses próprios deles. Os Akwẽ sabem conviver com duas culturas diferentes e com a natureza; sempre estão relacionados com saberes do passado" (XERENTE, 2012, p. 18).

Outra forma de identificação do povo Akwẽ é a pintura corporal, sendo que os clãs pertencentes à metade Wahirê são identificados pelo traço, que pode ser fino na horizontal (wahirê), médio na vertical (Krozake), ou grosso na horizontal (krãiprehi), para identificar a qual clã a pessoa pertence. Já as pessoas da metade Dói recebem em sua pintura corporal círculos pequenos (Kuzâ), médios (Kbazi) e grandes (Krito). Abaixo observaremos melhor essas representações clânicas:

Quadro 1 - Representação clânica.

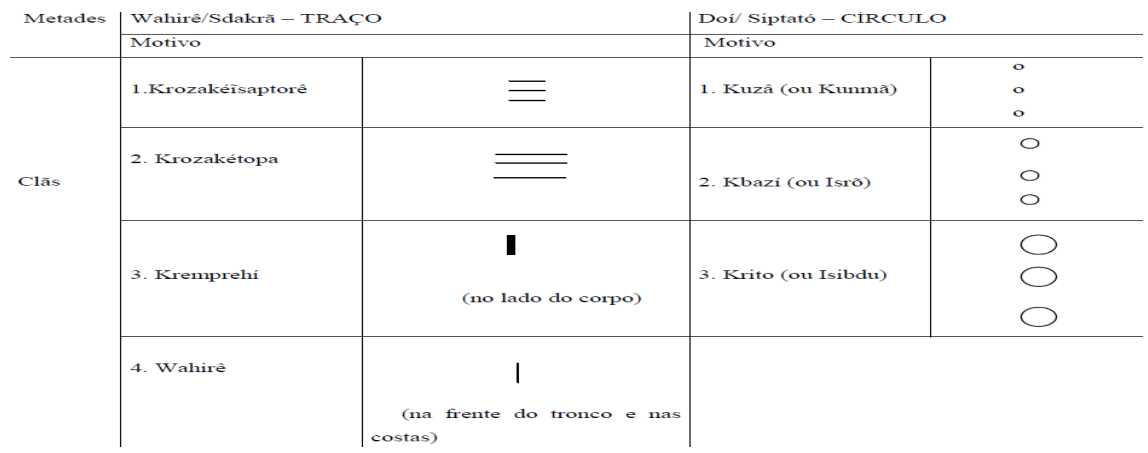

Fonte: Ivo Schroeder (2006).

Essas pinturas corporais ainda hoje são usadas pelos Akwẽ, e são uma forma de identificar cada família e, também, de repassar para as gerações futuras nossos conhecimentos organizacionais. 


\section{O contato entre falantes da língua Akwẽ e do português}

Segundo Silva (2014), os falantes de diferentes comunidades linguísticas estão em constante contato, o que faz com que as línguas não sejam consideradas isoladas. Nesse contexto de contato, surgem os tipos de bilinguismo ou até mesmo multilinguismo dentro das comunidades indígenas.

Segundo as pesquisas de Rodrigues (2002), o número de línguas faladas no Brasil está entre 180 a 200. Assim, Filho (2000) afirma que muitas comunidades indígenas ainda são monolíngues em suas línguas maternas.

Por bilinguismo, entende-se, de modo popular, "o uso regular ou alternado que um falante faz de duas ou mais línguas no seu cotidiano" (GROSJEAN 2001: apud SILVA 2014: 36). Porém, há várias outras definições para tal termo. Conforme a autora citada acima, são vários os fatores que levam uma comunidade a se tornar bilíngue, como os casamentos interétnicos, o contato com outros povos nas relações comerciais, políticas, a morada na cidade, e os processos de colonização que foram impregnados nas comunidades indígenas, dentre outros.

Pimentel da Silva (2009) corrobora com essa ideia e afirma que são várias as circunstâncias que fazem com que os indivíduos se tornem bilíngues, dentre eles, fatores sociais, políticos e históricos, originados do contato entre falantes de línguas diferentes.

Já de acordo com Grosjean (apud Filho, 2000), o bilinguismo é o uso de duas ou mais línguas sendo este uso determinado pela necessidade. Para Martiny \& Menoncin (2013), há várias definições de bilinguismo, porém destaquei somente uma delas, a seguinte: considera-se bilinguismo, o uso alternado de duas línguas, que pode se apresentar em diferentes níveis de conhecimento, sendo considerado desde o domínio mínino até o domínio abrangente de ambas as línguas.

Nessa ótica, as autoras enfatizam que "a condição de bilíngue passa a ser vista como dinâmica, pois parte-se do princípio de que o falante bilíngue é aquele que pode produzir enunciados orais ou escritos em mais de uma língua, a depender de sua necessidade de competência linguística comunicativa" (MARTINY E MENONCIN, 2013, p. 22).

Desse modo, o tipo o bilinguismo passa a ser observado de acordo com o grau de uso das duas línguas pelos falantes, o domínio e 
a variação de uso das mesmas. Para reforçar essa discussão, eu trouxe algumas notas produzidas em sala de aula no Curso de Educação Intercultural, sobre o conceito de alguns tipos de bilinguismo, criado por nós, alunos indígenas dos povos Akwẽ, Tapirapé, Javaé, Guajajara, Karajá, Krahô, Krikati e Gavião, em parceria com a professora Maria do Socorro Pimentel da Silva.

$\mathrm{O}$ bilinguismo responsivo se efetiva quando as pessoas entendem uma língua e falam outra.

Já no bilinguismo passivo, os falantes sabem uma língua e entendem um pouco de outra, mas não conseguem se comunicar em uma outra língua.

Há também o bilinguismo de memória. Nesse contexto, a língua materna fica na memória dos anciãos, mas não é mais usada, pois a língua de comunicação na sociedade é a portuguesa, no caso dos povos indígenas brasileiros.

Já no bilinguismo subtrativo, a língua portuguesa vai ocupando os espaços de uso da língua indígena. Para esse tipo de bilinguismo, Flory (2009) traz a seguinte definição: "bilinguismo Subtrativo, aquele em que a segunda língua é adquirida à custa da primeira, ou seja, ao adquirir uma segunda língua, perde-se a proficiência na primeira. Há também o bilinguismo Aditivo, aquele em que a segunda língua é adquirida sem perda de proficiência na primeira" (FLORY, 2009, p. 11).

Já no bilinguismo de revitalização, há lembrança da língua materna e, nesse caso, podem ser criadas políticas linguísticas para esse processo de revitalização.

Acredito, então, que o bilinguismo pode ser usado como instrumento de enriquecimento linguístico, porém, se for usado de forma correta, respeitando os espaços de uso de ambas as línguas.

Isso porque, geralmente, quando há línguas distintas em contato, é atribuído, de forma histórica, ideológica e política, um valor diferenciado a algumas delas. No caso do contato entre o português e a língua indígena, é dado mais privilégio à língua portuguesa, por estas razões citadas.

Nessa linha de pensamento, afirma Mori (1999) que, quando povos diferentes se encontram em um mesmo território, de certa forma, ocorre uma imposição da língua falada pela sociedade majoritária, pois esta possui maiores poderes sociopolíticos e militares, ou seja, há uma relação de diglossia na qual a língua oficial é sempre a do dominador, de forma que toda a comunicação entre 
sociedade e Estado precisa ser feita nessa língua. Assim, o uso das línguas indígenas fica mais restrito ao espaço da aldeia, nos eventos cotidianos.

Dessa forma, Martiny \& Menoncin (2013) afirmam que quando há o contato entre falantes de língua minoritária e de línguas majoritárias, há uma disputa desigual de forças, e que na maior parte das situações acaba emanando uma tensão entre essas línguas.

Portanto, observaremos que há cada vez mais aproximação entre essas culturas, pois as tecnologias estão adentrando as aldeias e, mesmo sem sair de casa, os indígenas, desde criança, já têm contato com a língua portuguesa. Além disso, na escola, há também a presença desse contato desde cedo, pois, mesmo tendo professores indígenas na maioria das escolas da reserva Xerente, os materiais que são usados por eles ainda são, em grande parte, na língua portuguesa e muito distante da realidade Akwẽ. Porém, ressalto que esse processo está mudando, ainda que timidamente, pois há alguns materiais confeccionados na nossa língua por professores indígenas em parceria com Universidades. Assim, Silva (2014) corrobora com essa ideia ao afirmar que

nesse sentido, contato massivo com a sociedade não indígena e, consequente, com a língua portuguesa, é algo que pode ser observado não somente pela introdução de novas tecnologias nas aldeias (internet, rádio, televisão, etc) como também pela crescente necessidade de comunicar-se em português. Seja para receber atendimento na área da saúde, para conseguir um emprego fora da aldeia, a relação com os não indígenas tem motivado o uso do português em cada vez mais situações de interação social (SILVA, 2014, p. 11).

O que se precisa saber é como lidar com esse contato linguístico de modo que o uso da língua portuguesa não enfraqueça a língua Akwẽ, então, cabe o seguinte questionamento: o que pode levar os falantes de uma língua indígena a usarem mais uma língua estrangeira, mesmo onde caberia sua própria língua? Melo (1996) afirma que essa atitude não somente é de ordem linguística, mas está relacionada diretamente com fatores sociais, econômicos, políticos, dentre outros fatores.

Nessa mesma linha de pensamento, Mori (2000, p. 6) afirma que, não só no Brasil, mas em toda América latina, "os falantes 
indígenas atravessam, desde o momento de seu contato com a sociedade ocidental, processos de desestruturação étnica" e que, em decorrência da situação de dominação socioeconômica, "os povos indígenas vêm cedendo aos mecanismos de suplantação de línguas em favor daquelas faladas pelo opressor", ou seja, vão se tornando monolíngues na língua majoritária.

Por isso, nesse trabalho discutiremos como está a situação atual da língua Akwẽ nesse contexto de contato com a língua portuguesa. Cabe ressaltar que segundo a pesquisa feita por Xerente (2012), a língua Akwẽ tem sofrido mudanças, porém continua sendo falada pela maioria dos pertencentes a esse povo e tem sido transmitida às novas gerações.

\section{Diagnóstico da situação sóciolinguística entre o Povo}

\section{Akwẽ}

\subsection{A Língua Akwẽ}

A língua Akwẽ pertence à família Jê, que faz parte do Tronco linguístico Macro-Jê. Do ponto de vista sociolinguístico, essa comunidade pode ser considerada como bilíngue, pois a maior parte desse povo faz uso de ambas as línguas, Akwẽ e portuguesa, e dos conhecimentos presentes nesses dois contextos. Há, dentro da reserva, casos de pessoas monolíngues em português, porém são casos isolados. Quanto ao monolinguismo em Akwẽ, observa-se que as crianças até aproximadamente os 06 anos se encaixam nesse perfil, conforme afirma Xerente (2012): “a criança fala somente a sua língua materna até os seis anos e quando frequenta a escola bilíngue na sua aldeia, começa estudar a língua portuguesa".

Assim, acredita-se que a criação de escolas dentro da reserva, postos de saúde e as relações comerciais, dentre outros fatores, contribuíram para a efetivação da situação linguística atual do povo Akwẽ, o que para alguns anciãos pode servir como ameaça se não for bem proveitoso o aprendizado, conforme veremos na fala de Darêkêkwa Xerente, "os jovens precisam acordar para poder valorizar a nossa cultura. Por outro lado, é bom buscar novos conhecimentos dos não índios para poder defender os direitos do Akwẽ’. 
Dessa forma, percebemos que os anciãos reconhecem que é importante aprender novos conhecimentos, mas sem permitir que eles prejudiquem a cultura do povo Akwẽ. E, sendo a língua um veículo fundamental de transmissão de conhecimentos, deve-se saber em que momentos é importante se apropriar da língua portuguesa, para que a mesma sirva como instrumento de defesa dos nossos direitos, como afirma acima o ancião, e não como mecanismo de negação da nossa própria identidade.

\subsection{Resultados da pesquisa de campo: um olhar Akwẽ sobre sua realidade linguística}

Para ter um levantamento mais concreto dessa realidade linguística, fui a campo trazer dados que subsidiarão as discussões desse trabalho. Descobri durante a pesquisa que a maioria dos entrevistados tem a língua Akwẽ como primeira língua, porém admitem que o português tem entrado no cotidiano da aldeia em contextos desnecessários. Podemos observar isso na fala de K.X, "com a capacidade que temos de nos comunicar entre si, conseguimos conversar ou traduzir qualquer assunto".

Nessa mesma linha de pensamento o professor I. S. X, afirma que "qualquer língua é suficiente para qualquer grupo, sem intervenção de outra língua”.

Observei também que a língua materna, em faixas etárias diferentes, possui um espaço privilegiado, apesar da entrada do português no cotidiano Akwẽ, conforme o seguinte relato: "a língua Akwẽ, o bem mais precioso que foi deixado pelos nossos antepassados, é a única coisa que ninguém jamais conseguirá nos tomar" (K.X.).

Descobri também em quais contextos o português aparece mais: no jogo de futebol, discussão sobre as políticas da cidade, na escola (onde há professores não indígenas) dentre outros.

Em relação à influência que o português tem tido nas mudanças ocorridas na língua $\mathrm{Akwẽ,} \mathrm{observei} \mathrm{que} \mathrm{há} \mathrm{a} \mathrm{entrada} \mathrm{do} \mathrm{português} \mathrm{no}$ nosso cotidiano, porém, temos sido resistentes e muito dos nossos conhecimentos tradicionais permanecem vivos e são transmitidos na língua Akwẽ, para as gerações mais novas.

Xerente (2012) corrobora com essa ideia e afirma que as políticas linguísticas do povo Akwẽ estão relacionadas com a 
organização social dos clãs, cujo princípio é o da patrilinearidade. Por exemplo, um homem wahirê se casa com uma mulher kuzâ: todos os filhos desse casal pertencem ao clã do pai, o clã wahirê.

Outros valores estão agregados a essa permanência dos conhecimentos tradicionais entre o povo Akwẽ, como o respeito e as formas de tratamento.

Segundo Xerente (2013), ocorreram algumas mudanças na língua Akwẽ, especialmente, no que diz respeito à influência do português, porém aqui apresentarei somente alguns exemplos de empréstimos linguísticos do português para esta língua, conforme veremos no Quadro 2 abaixo:

Quadro 2 - Exemplos de empréstimos linguísticos.

\begin{tabular}{|c|c|}
\hline Palavra em português & Empréstimo \\
\hline Tia & Titirê \\
\hline Mamão & Mãmã \\
\hline Alho & Aire \\
\hline Melancia & Mrãci \\
\hline Laranja & Rara \\
\hline
\end{tabular}

Fonte: Sílvia Letícia G. S. Xerente.

Quanto aos espaços de uso da língua Akwẽ, observamos que é usada em todos os espaços sociais de convivência desse povo, do qual também sou pertencente. Ela é a língua usada no cotidiano da aldeia, na comunicação familiar, na educação dos filhos, no trabalho, nos rituais, nas brincadeiras, no lazer etc.

Apesar disso, as crianças estão aprendendo cada vez mais cedo a língua portuguesa, pois, mesmo sem sair de casa, já tem o contato com ela, através de desenhos que passam na televisão, jogos no computador, e, quando entram na escola, e se deparam com o material didático que ainda é a maior parte pautada nos moldes da educação ocidental.

Podemos afirmar que a língua Akwẽ ainda é falada tanto no cotidiano, quanto nos espaços especializados, forma que aqui pretendi classificar os nossos rituais de nomeação, kupre, manifestações do pajé, cerimônia de casamento, dentre outros que falaremos mais a frente. 


\subsection{Espaços de uso da língua Akwẽ}

Conforme a pesquisa realizada, podemos observar que são vários os espaços de uso, tanto especializados, quanto cotidianos, da língua Akwẽ. Apresentamos, a seguir, alguns deles.

\subsubsection{Espaços cotidianos em que é usada a língua Akwẽ}

Kri (casa)- nesse contexto, a língua é usada para falar de vários assuntos, como as coisas que acontecem na aldeia, doenças, caçada, pescaria, educação dos filhos, e demais diálogos do cotidiano.

Bru (roça)- No momento do trabalho de plantação e colheita, a comunidade se reúne e a língua usada para a comunicação é a língua materna.

Pátio da Aldeia- Esse espaço, há algum tempo atrás, era conhecido como Warã, que segundo o ancião Raimundo K. Xerente: "Antigamente era a escola deles, onde aprendiam o suficiente para sobrevivência da língua, da cultura, das tradições e do povo". Hoje esse espaço é usado para as brincadeiras, reuniões, festas tradicionais, e mesmo não existindo mais o Warã, esse local é bem respeitado por todos os Akwẽ.

Local de Banho- Nesse ambiente, há uma interação muito grande entre os Akwẽ, pois todos se divertem, brincam, realizam atividades domésticas como lavar louças, roupas e a língua falada é a língua materna, pelos adultos, jovens e crianças.

Local de caça- Esse espaço é reservado aos homens, pois, segundo a cultura Akwẽ, os homens são os provedores dos alimentos da casa e, portanto, esses são responsáveis pela caça e pela pesca. Apesar de termos algumas mudanças nos hábitos alimentares do povo Akwẽ, com a introdução de alimentos industrializados, ainda é bem presente entre nós, a nossa alimentação tradicional, pois há rituais que precisam de caça e pesca, conforme afirma Srõne (2013, p. 19): "em várias ocasiões da vida do povo Akwẽ, tem se mostrado diversas formas de preparos, usos, práticas e tipos de alimentação tradicional. Durante a festa de nomeação conhecida entre os Akwẽ como Dasĩpê, há vários rituais que necessitam de alimentação tradicional específica".

Assim, nesses momentos de caçada e pesca, quando são coletivas, o uso de nossa língua materna está presente. Os ensinamentos sobre as técnicas de caça e pesca são repassados 
de pai para filho, através da língua materna, garantindo, assim, a sustentabilidade desses conhecimentos.

Local de colheita do capim dourado - Geralmente, a colheita do capim dourado é feita pelas mulheres Akwẽ e elas são responsáveis pela preparação desse material para a confecção dos artesanatos. Essa colheita é feita em grupos e, durante a colheita, há grandes trocas de experiências, conversas e uso da língua materna, principal ferramenta de compartilhamento dos nossos saberes.

Brejos - Nesse local, encontramos o buriti, que é utilizado de várias formas por nós. Do tronco é feito as toras que são utilizadas em atividades esportivas e festas tradicionais. Da palha é retirada a fita que é utilizada para fazer os acabamentos dos artesanatos de capim dourado e para a confecção de artesanatos de fita de buriti puros ou tingidos. Os frutos são utilizados para a alimentação e o óleo retirado dessa fruta serve para vários tipos de doenças. Homens e mulheres vão ao brejo, mas as atividades geralmente são divididas, as mulheres colhem os frutos, retiram a seda do buriti e retiram o óleo dessa fruta. Já os homens são responsáveis pela retirada e preparação da tora de buriti, utilizada em vários rituais do povo Akwẽ, como o Dasĩpê.

Assim, podemos observar que o uso da língua Akwẽ é muito importante para a manutenção dos conhecimentos do nosso povo, pois, em todos os espaços apresentados acima, as atividades realizadas não são aleatórias, há sempre uma troca de conhecimentos que se efetiva por meio da língua Akwẽ.

Além dessas áreas citadas acima, em várias outras, acontece o uso de nossa língua, o que mostra que o povo, mesmo tendo contato com não indígenas e povos de outras etnias, há alguns séculos, estão sempre praticando a língua Akwẽ e construindo conhecimento por meio dela.

Trataremos agora de alguns dos espaços especializados onde só se usa a língua Xerente, regra respeitada até hoje por todos os Akwẽ.

\subsubsection{Espaços especializados em que é usada a língua Akwẽ}

Nessa parte, tratarei alguns espaços onde é usada somente a língua Akwẽ; essa é uma regra passada de geração a geração e é bem respeitada pelo nosso povo. Falaremos então de alguns rituais, como 
eles acontecem, quem são os responsáveis por organizá-los e de que forma a língua é durante cada uma dessas etapas.

Antes de passarmos aos diversos espaços especializados, veremos o que significa a palavra "especializado". Segundo o dicionário, trata-se do "Lugar onde os serviços são oferecidos de caráter único, próprio, exclusivo, diz se de algo autêntico, pessoal e idiossincrático" (Dicionário online. www.dicio.com.br/ especializado/acessado em 29/05/18).

Assim são os rituais aqui apresentados, para o nosso povo eles são autênticos, próprios de nossa cultura e com valor inestimável para todos os Akwẽ.

Comecemos, então, pelo Dasĩpê. Essa festa é muito importante para o povo Akwẽ. Essa é uma festa bem organizada pelos anciãos, pois antes da realização da mesma, há reuniões para que seja decidido o local, a data e os rituais a serem realizados durante a festa. Para auxiliar os anciãos na organização dessa festa, são escolhidos mensageiros que ficam responsáveis por cortar a tora de buriti, preparar o jenipapo para a pintura corporal dos participantes e ajudar os anciãos no que for preciso durante a realização dessa festa.

Primeiro, é feita a nomeação das meninas. Se forem muitas, esse momento de nomeação pode durar vários dias. Após a nomeação das meninas, 'pikõi nĩsi', os homens partem para a mata para se preparar para a nomeação de meninos 'kwatbremĩ nĩsi'. Nesse local, somente os homens vão e sabem como é essa preparação, por isso, não posso dar muitos detalhes sobre essa parte.

Após essa parte de preparação dos homens, são escolhidos dois representantes de clãs diferentes, um homem e uma mulher denominados 'dakmãhrâkwa', nomeadores que representam, que são considerados donos das listras, e dois 'dazazêikwa' que confirmam os nomes e representam os donos dos círculos. Em cada festa de nomeação, somente duas mulheres escolhidas pelos anciãos vão até o local onde os homens ficam se preparando para a nomeação dos meninos. Lá, são preparadas para o momento de nomeação.

Após essa preparação, os homens saem da mata em duas fileiras acompanhados pelos nomeadores: dakmãhrâkwa e dazazêikwa, até o pátio onde acontece a nomeação. Depois desse momento, acontece o ritual do Padi e para encerrar, tem a corrida de tora grande (Ísitro).

$\mathrm{O}$ que quero aqui ressaltar é que, durante toda essa festa, desde sua preparação até sua finalização, são muitos conhecimentos que estão presentes e são repassados através da língua Akwẽ. Nessa 
festa, o uso da nossa língua é feito por todos e, mesmo quando há visitas, não há tradução do que está sendo falado durante os rituais.

Outro ritual importante é o Damrõze (casamento). O casamento do povo Akwẽ deveria acontecer entre pessoas de clãs diferentes, porém, hoje, as coisas estão mudando e já acontecem casamentos entre pessoas do mesmo clã. Geralmente, os jovens Akwẽ não namoram muito tempo, assim que os pais descobrem que a filha está namorando, fazem reunião com os pais do namorado para realizar o casamento.

O tio da noiva é responsável por organizar esse ritual, que é bem breve. Após os noivos pintados e enfeitados, começa-se o casamento. Então, a noiva sai do local onde se arrumou, juntamente com os seus familiares e o seu tio, até a casa do noivo, onde acontece o casamento. A noiva leva consigo alimentos, e entrega para o seu noivo, esses alimentos são preparados pela esposa do tio da noiva.

A família da noiva também leva alimentos para o noivo, e após entregá-los, a noiva senta-se ao lado do noivo, que fica à sua espera, sentado em uma esteira. Após esse momento, dois anciãos fazem o discurso, falando das responsabilidades do casal, dos direitos e deveres deles e das duas famílias que se unem a partir dessa data.

Para finalizar, a família do noivo faz o ritual de choro, junto com o noivo, pois, após casar-se, o rapaz acompanha a noiva, para sua aldeia, onde passa a morar, juntamente com os sogros.

A família é uma instituição muito sagrada para o povo Akwẽ. No ritual de casamento, é presente sempre a língua Akwẽ, e acredito que sem essa língua seria difícil organizar esse ritual, que parece simples, mas possui um significado muito grande para todos os Akwẽ.

Já o Kupré é o nome que se dá a cerimônia realizada após o funeral. Segundo os anciãos, ela faz parte da história do povo Akwẽ e é considerada um ritual sagrado. A realização acontece na visita do sétimo dia.

Segundo Tpêkru Xerente (2011), hoje esse ritual acontece da seguinte maneira: os homens do clã da falecida(o) se reúnem com os anciãos na mata, então escolhem duas meninas dos mesmos clãs e as enfeitam. Após essa preparação, saem da mata em fileiras e ainda segundo o autor: 
Ao sair da mata, os homens, acompanhados das duas meninas, dirigem-se a casa da falecida (o), com uma vara na mão. Batendo-o fortemente no chão, todos pulam num só ritmo, soltando um som que parece um gemido. Chegando a casa onde toda a família está reunida com as demais pessoas, eles se colocam diante da família e choram, expressando a dor da perda daquela pessoa (TPÊKRU, 2011, p.75).

Após esse momento, seguem para o cemitério, em fileiras, repetindo os mesmos movimentos rítmicos. Ao chegar em frente ao túmulo, os homens continuam em duas fileiras, e o pajé começa a realizar o ritual de choro novamente e todos os demais dão continuidade ao ritual de kupre. Depois, os homens começam a pular por cima da sepultura, de um lado para o outro, porém, ninguém pode triscar nela ou cair sobre a mesma, pois se isso acontecer, segundo os anciãos, essa pessoa pode morrer.

Para finalizar o ritual, os homens retornam à casa da família que se encontra em luto, realizam o ritual de choro, juntamente com a família, e depois retornam para a mata e lá recebem agrados, que são carne de caça, peixe, farinha e outros alimentos, e assim termina esse ritual.

Falaremos agora dos discursos. Desde cedo, nós Akwẽ aprendemos a valorizar os ensinamentos repassados pelos anciãos através do discurso. Eles nos ensinam também que o respeito é o pilar fundamental para a organização do povo Akwẽ.

Assim, os Pẽikwa (Conselheiros da paz) são responsáveis por manter esse respeito dentro da nossa comunidade. Segundo Warõ Xerente, "'a função deles é ensinar e dar conselhos que possam ser utilizados em meio a conflitos, contribuindo para que todos na aldeia vivam em harmonia." Quando eles discursam, todos precisam prestar muita atenção, pois o que falam é sempre muito importante para a nossa convivência em comunidade.

Todos os ensinamentos passados por eles são através de nossa língua materna, promovendo, assim, a valorização dos conhecimentos tradicionais, da cultura, da língua e da oralidade. Assim, através da preservação da nossa língua, podemos a cada dia fortalecer as expressões culturais do povo Xerente, reconhecendo a sua importância para sustentabilidade cultural e garantindo aos mais jovens esse grande aprendizado. 


\section{4 Ánalise dos dados coletados}

Nessa parte, trarei da análise dos dados coletados durante a pesquisa de campo. Elaborei um questionário, que foi aplicado a várias pessoas, de diferentes faixas etárias, regiões e gênero. Gostaria de saber a perspectiva dos Akwẽ sobre sua realidade sociolinguística e a avaliação que os mesmos fazem sobre o contato deles com a língua portuguesa. Nesse questionário, havia perguntas abertas, que permitiam ao participante colocar seu ponto de vista sobre determinados assuntos tratados nele.

Durante a coleta de dados, também conversei com vários anciãos que me deram subsídios para a discussão do tema em questão e me ajudaram a entender a atitude afetiva dos falantes em relação às duas línguas em contato: Akwẽ e português.

Esse questionário é composto de dezoito questões que enfocavam o conhecimento das duas línguas, o uso dessas línguas em diferentes contextos sociais e atitudes dos falantes em relação as mesma. Além disso, ressaltamos o domínio da língua, tanto falada quanto escrita, a importância que o indivíduo dá a ela, em que momento ela é usada, em que momentos há a necessidade de falar em português e por quê. Tivemos também, com esse questionário, o objetivo de descobrir se o português influencia nas mudanças que vêm ocorrendo na língua Akwẽ.

Para se ter dados concretos da realidade sociolinguística do povo Akwẽ, apliquei questionários para pessoas de nove aldeias diferentes, sendo elas: Funil, Vão Grande, Cercadinho, Boa Esperança, Brejo Comprido, Zé Brito, Boa Vista, Porteira e Baixa Funda. Além disso, foi aplicado questionário em Tocantínia, para algumas famílias de indígenas que residem na zona urbana, e também na escola CEMIX que possui pessoas de várias aldeias da Reserva Xerente.

Foi um período muito difícil, pois tive que me ausentar muitas vezes da minha residência em busca dos dados, em dias de chuva e de sol, porém, acredito que valeu a pena, pois estou conseguindo registrar um pouco dos conhecimentos sobre meu povo.

Nas visitas às aldeias, tive a oportunidade de conversar com pessoas mais experientes que contribuíram com minha pesquisa, como alguns professores e anciãos.

Essa troca de conhecimento é muito importante para a sustentabilidade dos nossos saberes tradicionais que são passados de 
geração em geração, através de nossa língua materna. Abaixo, trarei os dados colhidos durante a pesquisa.

A cultura Akwẽ é patrilinear, isso é respeitado durante todo o ciclo de vida do povo Akwẽ. As mulheres se dedicam mais às atividades domésticas, à confecção dos artesanatos e à educação extraescolar dos filhos. Quando cheguei às aldeias para fazer minha pesquisa, poucas mulheres se pronunciaram, muitas se envergonham por não possuírem uma escolarização e outras, por respeito ao esposo, deixam que o mesmo responda às perguntas e somente se pronunciam com a autorização do mesmo, principalmente se o pesquisador for homem.

Como pertencente a esse povo, tive mais facilidade na conversa com as mulheres, pois sempre que chegava às aldeias começava primeiro conversando com as mesmas sobre assuntos como os filhos, alimentação e artesanatos e, nisso, já ia observando as línguas usadas por elas com os filhos. Assim, ia enriquecendo minha pesquisa.

Quando ia entrevistar homens, procurava ser o mais objetiva possível, com poucas conversas e mais aplicação das questões norteadoras do estudo, por uma questão de respeito, por nós designado com wasiwaze 'nosso respeito mútuo' às particularidades da organização social do nosso povo. Apesar disso, conforme veremos abaixo, a maioria dos entrevistados foi homem. Passemos ao perfil dos entrevistados na minha pesquisa.

\section{Perfil dos entrevistados: gênero}

Gráfico 1 - Gênero dos entrevistados.
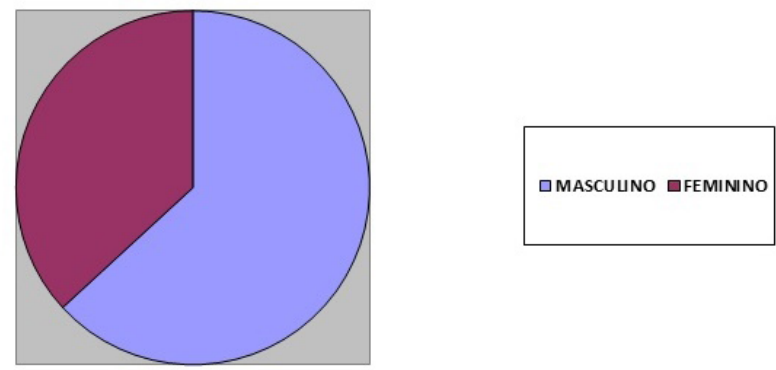

Fonte: Sílvia Letícia G. S. Xerente. 


\section{Faixa etária dos entrevistados}

Uma hipótese da qual parti é a de que os jovens Akwẽ estejam falando mais português que as pessoas de faixas etárias mais avançadas, pois conforme afirma (Braggio apud Silva, 2014:11): "há uma disputa entre a língua indígena e o português pelos diferentes espaços/nichos comunicativos da comunidade".

Ainda nessa linha de pensamento, a preocupação que trago aqui, subsidiada pela ideia de Braggio (2012), é a de que o futuro de nossa língua materna e cultura Akwẽ estão nas mãos dessa geração mais nova, os Wapte e, conforme suas atitudes, teremos valorização linguística, enfraquecimento, ou até mesmo morte da nossa língua. Pois ainda segundo Silva,

o conflito português-xerente como um efeito do cenário de tensão sociocultural e política estabelecido é manifestado tanto no comportamento linguístico do grupo, na medida em que se verifica uma superposição crescente do português (língua dominante) em relação à língua indígena (língua dominada), onde a língua portuguesa recebe cada vez mais funções e prestígio dentro da comunidade xerente, como em suas atitudes com relação à língua em contato (SILVA, 2014, p.11).

Dessa forma, verificaremos, então, no decorrer da pesquisa, se essa hipótese se comprova. Para isso, vejamos o gráfico abaixo que apresenta a quantidade de entrevistados por faixa etária e sexo.

Gráfico 2 - Idade x Sexo.

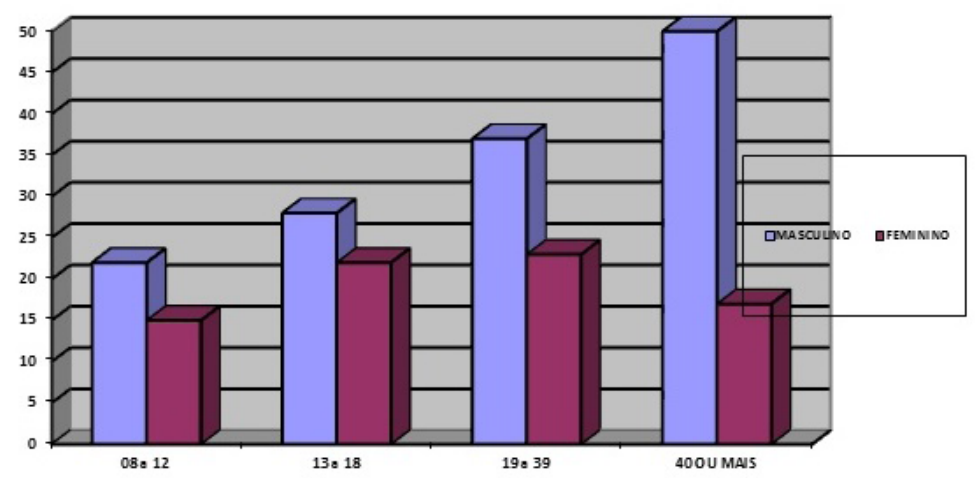

Fonte: Sílvia Letícia G. S. Xerente. 
Procurei abranger muitas pessoas de cada faixa etária/sexo, em diferentes regiões, para trazer dados concretos e abrangentes sobre a realidade sociolinguística do povo Akwẽ. Esta foi uma tarefa bastante árdua, mas que me proporcionou um aprendizado único sobre a minha língua materna e a situação em que se encontra atualmente.

\section{Escolaridade dos entrevistados}

Além disso, quis também investigar se o fator escolaridade influencia nesse processo de aprendizado e uso da língua portuguesa pelos Akwẽ. Vejamos, abaixo, no Gráfico 3, o nível de escolaridade dos entrevistados.

Gráfico 3 - Escolaridade.

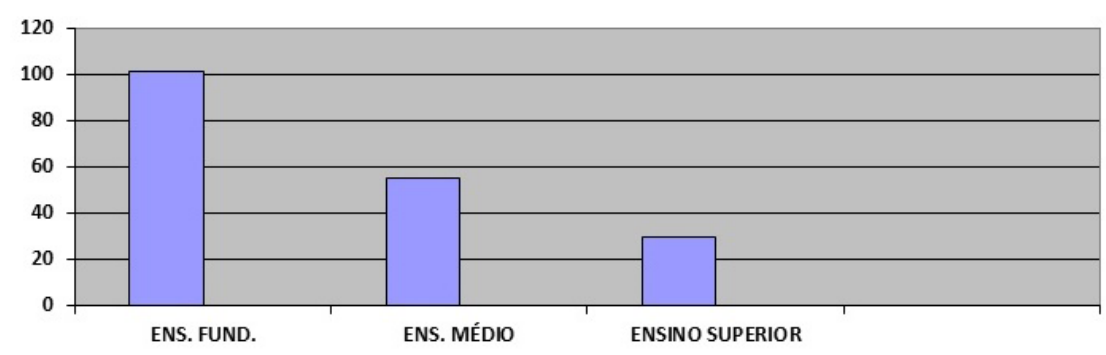

Fonte: Sílvia Letícia G. S. Xerente.

O número de pessoas que possuem um maior nível de escolaridade ainda é menor dentro do povo Akwẽ, mas tende a crescer pelas facilidades de acesso que estamos tendo ao ensino superior. Segundo Waikazate e Sirnãwe,

na família Akwẽ a Educação é ensinada na própria casa quando os pais repassam todas as regras de respeitos para os seus filhos. Eles contam todas as histórias sobre os clãs, os parceiros que são respeitados de todos os clãs, a partir daí as crianças vão sabendo para a escola. Na escola só complemento os ensinamentos que eles aprenderam em casa (WAIKAZATE e SIRNÃWE, 2014, p.5). 
Mesmo recebendo a primeira educação no ambiente familiar, os Akwẽ estão a cada dia aumentando o nível de escolaridade, uma conquista para o nosso povo, pois pode ser visto como um meio de nos capacitarmos cada vez mais e nos tornarmos autônomos e gestores de nossos processos de ensino, saúde e demais áreas.

Para isso, contamos com 30 escolas dentro da nossa Terra indígena, que oferecem Ensino Fundamental na modalidade regular e EJA, Ensino Médio também nas duas modalidades mencionadas anteriormente, além de cursos Técnicos Profissionalizantes, conforme afirmam Waikazate e Sirnãwe:

na maioria das aldeias, as escolas são de ensino fundamental, com turmas multiseriadas. Somente no CEMIX (Centro de Ensino Médio Indígena Xerente), que fica localizado próximo à aldeia Coqueiro, tem ensino médio. No CEMIX é oferecido ensino médio regular e profissionalizante. Já são oferecidos dois cursos profissionalizantes: técnico em enfermagem e técnico em informática. Tem muitas escolas que já têm EJA (Educação de Jovens e Adultos), como as escolas das aldeias Brejo Comprido e Salto, por exemplo. Na aldeia Salto, tem um centro municipal de Educação Infantil (WAIKAZATE e SIRNÃWE, 2014, p.5).

Quanto ao Ensino Superior, os Akwẽ têm que se deslocar até a cidade de Miracema ou Palmas para estudar. Há também o nosso caso, que estudamos em Goiânia no Curso de Educação Intercultural, conforme demonstram os autores citados anteriormente: "muitos jovens Akwẽ já estão cursando ensino superior na Universidade Federal de Tocantins, Universidade Federal de Goiás, na Faculdade ITOP (Instituto Tocantinense de Educação e Pesquisa) e em outras universidades" (Waikazate e Sirnãwẽ, 2014, p. 10).

Segundo Silva (2014), a educação escolar do povo Akwẽ tem como proposta o ensino bilíngue. Porém, há uma diferença entre o que está previsto em lei e o que ocorre nas escolas indígenas, pois o que se observa é que o português tem mais prestígio dentro do ambiente escolar do que a nossa língua materna, e um ensino bilíngue não se concretiza num ambiente em que haja a presença de desigualdades de tratamento entre as línguas e conhecimentos envolvidos. 
Assim, nos preocupamos com o tipo de educação que está sendo desenvolvido dentro de nossas aldeias, pois, dependendo da forma como é desenvolvida, pode representar ponto positivo paras os nossos saberes/língua indígena ou um fator de negação de nossos conhecimentos.

Leme (2009, p. 23, apud KETI 2012, p. 46) faz referência à psicologia cultural defendida por Gerome Bruner e diz que "(...) a escola, como sistema baseado na autoridade, corre o risco de promover a alienação, oposição e incompetência, e em última instância, comprometer a própria cultura".

Assim, defendo uma educação que permita a valorização dos conhecimentos tradicionais do meu povo indígena e utilize esses conhecimentos para a construção de novos saberes universais, que garanta uma educação humanista a nós indígenas, conforme defendem as autoras,

entendermos que a educação é um processo de humanização, que ocorre na sociedade humana com a finalidade explicita de tornar os indivíduos em participantes do processo civilizatório e responsáveis por levá-los adiante. Enquanto prática social é realizada por todas as instituições da sociedade. Enquanto processo sistemático e intencional ocorre em algumas, dentre as quais se destaca a escola. E educação escolar, por sua vez, está assentada fundamentalmente no trabalho dos professores e dos alunos. A finalidade desse trabalho- de caráter coletivo e interdisciplinar e que tem como objeto o conhecimento- é contribuir com o processo de humanização de ambos, numa perspectiva de inserção social crítica e transformadora. (PIMENTA, ANASTASIOU, 2002, p. 80 apud CARVALHO, 2008, p. 155).

Assim, o que desejamos é uma educação com princípios pedagógicos que nos permitam a cada dia nossa ampliação de conhecimentos, que nos permitam também uma formação plena, que nos tornem aptos a exercermos nosso papel de cidadãos críticos e reflexivos, sem esquecermos nossa identidade indígena. 


\subsection{Atitudes linguísticas em contextos intraculturais}

Para sabermos como está a situação da língua Akwẽ dentro das aldeias, fiz perguntas para pessoas de faixas etárias diferentes. Passo a discutir os resultados de cada pergunta, feita e respondida no questionário. A primeira pergunta foi: Você sabe falar a língua Akwẽ?

A partir da análise das respostas fornecidas pelos entrevistados, obtive o seguinte resultado: apenas $4 \%$ dos entrevistados afirmaram não saber a língua indígena, essas pessoas são monolíngues em português, enquanto que $96 \%$ afirmaram saber. Ressalto que desse percentual, todos são bilíngues, porém apresentam tipos diferentes de bilinguismo, pois há pessoas que têm o conhecimento mínimo da língua portuguesa, até outras que dominam, de forma abrangente, essa língua e os conhecimentos inerentes a ela. Veremos abaixo a representação gráfica desses dados.

Gráfico 4 - Domínio da língua Akwẽ.
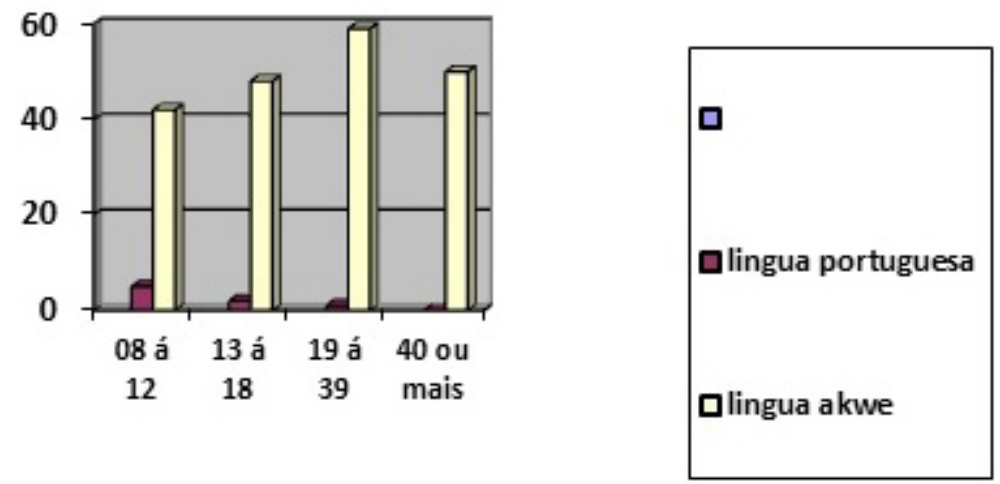

Fonte: Sílvia Letícia G. S. Xerente.

Observemos que a concentração de pessoas que é monolíngue em português se dá entre os mais jovens, ou seja, entre pessoas com 08 e 18 anos. Entre os falantes com mais de 40 anos, não registrei monolingues em português.

Segundo Waikazate e Sirnãwe, além da língua portuguesa, há outras línguas faladas dentro do território Xerente: "as línguas faladas são: língua materna, português, Javaé, Krahô, Xavante, Karajá, Xakriaba, Guajajara, Krikati, Apinãjé, Guarani, Bororo” 
(WAIKAZATE e SIRNAWE, 2014, p. 12). Porém, segundo eles, as línguas mais faladas dentro das aldeias é mesmo o Akwẽ e português.

Ainda nessa mesma linha de pensamento, Silva (2014) afirma que "as escolhas dos falantes funcionam como um espelho que reflete e retrata as percepções do grupo acerca dos outros e de si mesmos, apontando para os sentimentos positivos ou negativos e percepções que os indivíduos possuem acerca das línguas e de seus usos" (SILVA, 2014, p. 42).

Percebo, portanto, que apesar do contato massivo dos Akwẽ com o português, a língua ainda encontra-se forte em maior parte, em todas as idades pesquisadas; isso representa o respeito que os falantes Akwẽ têm por sua língua.

Para entender qual atitude os Akwẽ têm em relação ao domínio da sua língua materna, fiz, então, a seguinte pergunta: Você acha importante saber a língua Akwẽ? Os resultados obtidos foram:

Gráfico 5 - A importância de falar a língua Akwẽ.
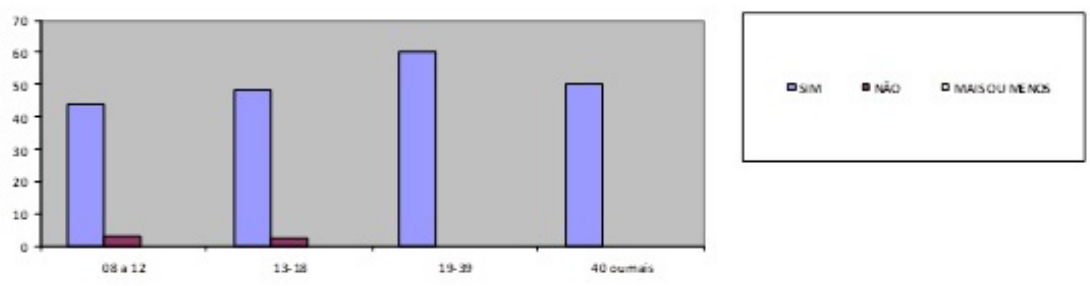

Fonte: Sílvia Letícia G. S. Xerente.

Podemos observar que a maior parte dos entrevistados acredita que é importante o uso da língua materna. Apenas uma pequena parte dos jovens entre oito e dezoito anos responderam que não. Os adultos e anciãos responderam que é importante o uso da língua materna. Esses dados demonstram o respeito que os adultos e anciãos têm pela língua, cultura, e conhecimentos próprios do nosso povo. Silva corrobora com essa ideia e afirma que "isso se deve ao fato de que, para estes, o uso do português sem que haja necessidade representa uma falta de respeito não só com os mais velhos, mas com a cultura e a identidade de ser Xerente" (SILVA, 2014, p. 66).

Quanto aos jovens, mesmo esses que declararam não achar importante o uso da língua Akwẽ, quando se deparam num diálogo com os wawẽ (ancião), precisam usar a nossa língua como um sinal de respeito aos nossos conhecimentos. 
Trago uma reflexão aqui quanto a essa atitude dos wapte (jovem) de não achar a língua Akwẽ importante. Hoje, existem somente cerca de 180 línguas indígenas faladas no Brasil, muitas foram extintas por vários fatores. Com isso, essas comunidades que perderam suas línguas, perderam também muitos de seus costumes, tradições, bem como conhecimentos que são repassados de geração a geração.

Acredito que, se esses wapte não mudarem de ideia, pode ocorrer uma perda linguística para o povo Akwẽ e, consequentemente, as particularidades da nossa cultura, pensamentos, visões de mundo, dentre outras coisas importantes para o fortalecimento da identidade de um povo.

Quanto à terceira pergunta do questionário, Você sabe escrever e ler na língua Akwẽ?, para a análise de tal questão farei uma breve reflexão sobre o que vem a ser ler e escrever. Segundo o Dicionário Online, "a leitura é a forma como se interpreta um conjunto de informações (presentes em um livro, uma notícia de jornal, etc.) ou um determinado acontecimento. É uma interpretação pessoal".

Há outras concepções para leitura que não podem ser aqui descartadas, como a leitura de mundo, que vem em complemento a leitura das palavras, conforme afirma Freire (1985), todo ser humano é capaz de fazer a leitura de mundo e essa vem antes da leitura das palavras. Esse tipo de leitura se faz muito presente no povo Akwẽ, pois muitos, mesmo sem serem alfabetizados, sabem fazer uma perfeita leitura do mundo que o cerca.

Mas para subsidiar a discussão da pergunta, partirei do primeiro conceito de leitura aqui apresentado, ou seja, leitura é um modo particular que o individuo tem de ver e interpretar o mundo ao seu redor, através do sistema da escrita alfabética.

Quanto à escrita, entendo por escrita a ação de expressar algo através de símbolos numéricos e alfabéticos, e assim expressar sentimentos, informações, notícias, dentre outros. Então, considerei, para a análise do Gráfico 6, abaixo, uma pessoa que sabe escrever, não somente o que faz a representação desses símbolos de forma aleatória, mas também que compreende o que se escreve.

Observaremos o Gráfico 6, abaixo, como está essa questão da escrita e leitura no povo Akwẽ: 

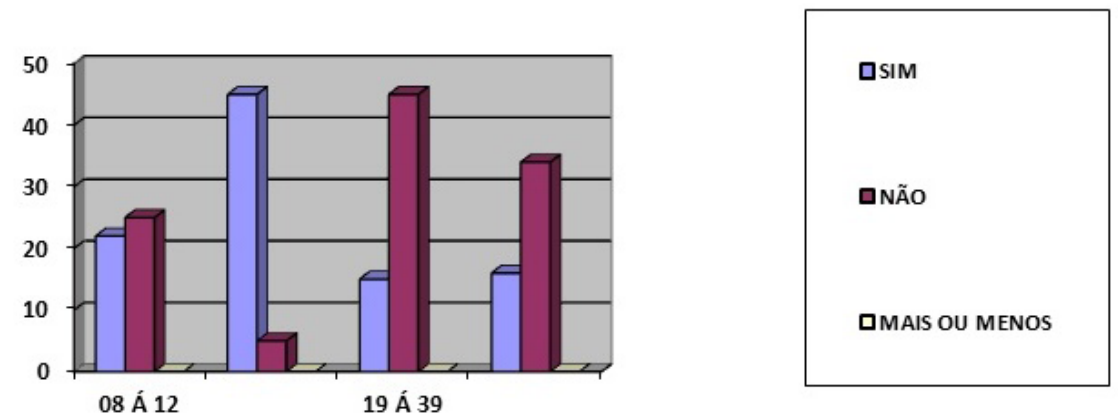

Fonte: Sílvia Letícia G. S. Xerente.

Quando se trata da leitura e escrita na língua Akwẽ, tem-se um movimento muito interessante, pois enquanto a maioria dos mais jovens afirma saber ler e escrever na língua Akwẽ, os adultos e anciãos afirmam não saber. Isso se dá por conta do processo de mudança que ocorreu na educação escolar indígena a partir dos anos noventa.

Antes desse período, o modelo de educação escolar era pautado pela catequização, civilização e integração forçada dos indígenas à sociedade nacional. Para se adaptar a essa lógica, as escolas implantadas dentro das aldeias não ensinavam a língua Akwẽ, por acreditarem que esta tinha menor prestígio que a língua portuguesa, que é vista como dominante. E, além disso, as escolas que havia dentro das aldeias, só ministravam aulas até a $4^{\text {a }}$ série do ensino fundamental, e quem desejasse continuar seus estudos, precisavam se deslocar até a cidade de Tocantínia para estudar.

A política de Educação escolar indígena passou a merecer maior atenção, a priori com a CF de 1988, em especial no artigo 210, o qual determina que devem ser "fixados conteúdos mínimos para o ensino fundamental, de maneira a assegurar formação básica comum e respeito aos valores culturais e artísticos, nacionais e regionais".

No parágrafo segundo, recomenda-se que "o ensino fundamental regular será ministrado em língua portuguesa, assegurada às comunidades indígenas também a utilização de suas línguas maternas e processos próprios de aprendizagem", partindo da reflexão do que está previsto em lei para a educação indígena. 
Enquanto norma constitucional, percebemos um grande avanço para a melhoria da educação indígena, ao passo que se reconhece oficialmente a diversidade cultural e linguística e confere aos povos indígenas o direito a um aprendizado em língua indígena, ou seja, a um ensino diferenciado (culturalmente adaptado aos modos de vida dos povos indígenas).

Com esse avanço, as crianças e jovens têm o privilégio de serem alfabetizados em suas línguas maternas, e isso contribui de forma positiva para a sustentabilidade dos nossos conhecimentos.

Quando perguntei se tem assuntos que é difícil conversar na língua Akwẽ, ainda houve pessoas que responderam sim, porém, foram poucas pessoas, se levarmos em conta o número de entrevistados, conforme veremos abaixo, no Gráfico 7:

Gráfico 7 - Há assuntos difíceis de se falar em Akwẽ?


Fonte: Sílvia Letícia G. S. Xerente.

Na pergunta seguinte perguntei quais são esses assuntos difíceis de conversar em Akwẽ. Os entrevistados me relataram que é futebol, políticas externas e relações comerciais. Essa dificuldade relatada pelos falantes de Akwẽ se dá pelo fato de haver uma disputa de posição entre a língua indígena e a língua portuguesa dentro das aldeias Akwẽ. Nessa disputa, em alguns casos, como os citados acima, a língua considerada majoritária, a portuguesa, acaba recebendo mais prestígio que a língua indígena.

Segundo Nascimento (2012, p. 51), há nessa atitude apresentada acima, um contexto de diglossia, pois, "os falantes elegem a língua de maior status social e não a sua língua materna, porque os espaços de uso de sua língua nativa se reduzem a âmbitos mais informais, como a comunidade e a família".

Se consideramos esse autor, apesar do quadro apresentado acima, é possível manter as línguas indígenas: "fortalecendo atitudes 
e valores próprios da cultura, a partir da escola com eixo principal e com a comunidade e, especificamente, com a família para formar um todo integrado" (NASCIMENTO, 2012, p. 53).

Considero importante a ideia do autor, pois isso foi claramente comprovado na pergunta seguinte: Tem assuntos que só podem ser tratados na língua Akwẽ?

Gráfico 8 - Há assuntos que só se fala em Akwẽ?

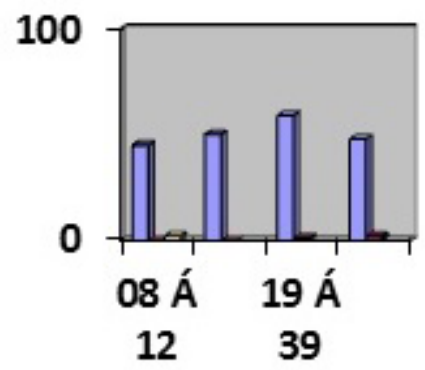

\section{口SIM \\ 口NÃo \\ DMAIS OU MENOS}

Fonte: Sílvia Letícia G. S. Xerente.

Quanto a esses assuntos, foram citados os seguintes: reuniões internas, resolução de problemas da escola da aldeia, o discurso do wawẽ, sobre os clãs, casamentos tradicionais, festas indígenas, assuntos relacionados à convivência Akwẽ e aos nossos costumes, ensinamentos dos anciãos sobre formas de tratamento, respeito, dentre outros aspectos.

Assim, acredito que o uso da língua Akwẽ vai além dos contextos informais, pois muitos dos nossos conhecimentos mencionados acima são tratados somente em nossa língua materna, e são considerados pelo povo Xerente como formais e de fundamental importância para todos os Akwẽ.

Essa atitude demonstra resistência ao processo de dominação imposto pela língua portuguesa dentro das nossas aldeias, e é visto como ponto positivo, pois apesar de termos um contato massivo com essa língua, sabemos usá-la de forma cautelosa, não permitindo que a mesma sirva como ferramenta de extermínio de nossa língua materna.

Dando continuidade, fiz a seguinte pergunta: Se você não sabe ou se não soubesse, gostaria de aprender a língua Akwẽ? 
Com as respostas, gostaria de saber qual o tipo de sentimento os Akwẽ atribuem a sua língua materna. Observaremos abaixo, no Gráfico 9, a representação das respostas:

Gráfico 9 - Respeito pela língua Akwẽ.
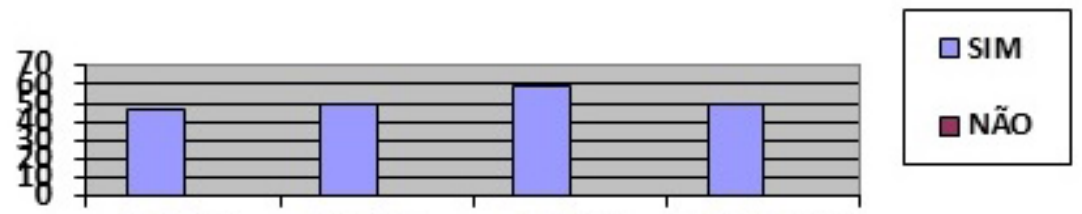

\section{8 Á $12 \quad 13$ Á $18 \quad 19$ Á $39 \quad 40$ OU MAIS}

Fonte: Sílvia Letícia G. S. Xerente.

Acredito que as respostas evidenciam o valor que o povo Akwẽ dá à sua língua, pois todos os entrevistados responderam que sim, inclusive os que são monolíngues em português.

Waikazate e Sirnãwẽ (2014) enfatizam a importância dessa valorização, conforme veremos a seguir:

então é os próprios Xerente que são preservadores da sua própria língua materna principalmente a fala, conversar só em Akwẽ, para se comunicar só em língua mãe, porque a língua falada é único meio para se defender, é a principal arma para os Akwẽ se defender, para os velhos a língua materna é uma arma muito forte para ser valorizada, porque se perdemos a língua materna o jeito de se comunicar é muito ruim para o povo Akwẽ (WAIKAZATE e SIRNÃWẼ, 2014, p.28).

Esse tipo de atitude alegra os anciãos Akwẽ, pois o desejo deles é que as crianças e jovens não percam o interesse pela sua língua e que a cada dia valorizem-na para que a mesma se torne mais rica e resistente.

\subsection{Usos linguísticos em contextos interculturais}

Nesse tópico, farei reflexões sobre a segunda parte do questionário que trata do contato linguístico do Akwẽ com o 
português. Para reforçar a discussão, uso como base algumas leituras como Silva (2010), Nascimento (2012), Munduruku (2002), Wdêkruwe (2012), dentre outros autores que abordam o uso do português por comunidades indígenas. Além disso, conversei com os anciãos Kakbupre, Wareti e Kanõse sobre esse assunto, o que me ajudou muito nas reflexões aqui apresentadas.

Conforme as leituras feitas, percebo que por muitos anos, os povos indígenas foram obrigados a acreditar que sua língua indígena era menos importante que a língua portuguesa, isso causou uma grande desigualdade entre os conhecimentos dos indígenas e dos não indígenas. Nesse processo, o conhecimento do não indígena era considerado o verdadeiro, enquanto os conhecimentos indígenas ficavam em segundo plano.

Dessa forma, muitos povos indígenas acabaram perdendo sua língua materna, conforme afirma Silva, "em 1500, no lugar em que hoje temos o território brasileiro, falava-se cerca de 1300 línguas indígenas. Atualmente, entretanto, restam apenas aproximadamente 180 línguas" (SILVA, 2010, p.3).

Nesse contexto, a língua portuguesa passa a assumir o papel de ameaçadora à língua indígena, uma vez que chega de forma silenciosa e ocupa o espaço dentro das comunidades.

Conforme afirma Nascimento (2012), "por outro lado a língua portuguesa se apresenta como um importante meio de comunicação intercultural, seja com a sociedade não indígena, ou com outros povos". Assim, cabe a cada povo avaliar as formas de uso dessa língua para que a mesma não se torne uma ameaça para a língua indígena e que seja somente a língua das relações interculturais.

Faremos agora uma análise do uso do português pelo povo Akwẽ, conforme os dados colhidos na pesquisa de campo.

A primeira pergunta que fiz sobre esse assunto foi: Qual a primeira língua que você aprendeu quando criança? Então, obtivemos os seguintes números, trazidos pelo Gráfico 10: 
Gráfico 10 - Primeira língua adquirida.

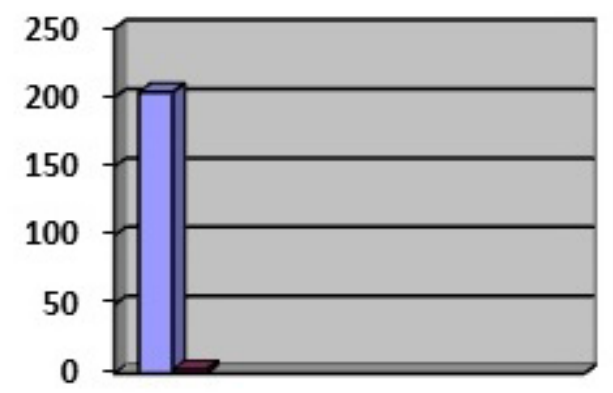

口AKWE

QPORTUGUÊS

Fonte: Sílvia Letícia G. S. Xerente.

Dentre os entrevistados, apenas três pessoas disseram ter a língua portuguesa como primeira língua. Perguntei, então, porque isso ocorreu, pois essas três pessoas moram em aldeias. Então, essas pessoas me relataram o seguinte: a primeira disse que seu pai é indígena e sua mãe é branca, e como a mãe tinha uma relação direta com ela, aconteceu a aquisição da língua portuguesa primeiro. Porém, com o contato com as outras crianças, ela acabou aprendendo o Akwẽ e hoje ela domina as duas línguas.

A segunda pessoa relatou que sua mãe é Akwẽ e quando ela nasceu, morava na cidade e seu pai é não indígena. A mãe dela optou por ensinar a língua portuguesa para ela. Os pais se separaram e ela ficou morando com o pai na cidade, e sempre que possível visita os parentes na Aldeia. Segundo ela, hoje consegue se comunicar em Akwẽ, porém não sabe muita coisa dessa língua.

A terceira pessoa tem a mãe mestiça (pai Akwẽ e mãe não indígena), essa senhora foi criada pela vó na aldeia, e na adolescência foi morar na cidade onde conheceu o pai do entrevistado que é não indígena. A mãe sabe a língua Akwẽ, porém não ensinou aos filhos, por isso os mesmos só falam a língua portuguesa, mesmo quando estão na aldeia. Dessas três pessoas, duas moram na Aldeia e uma na cidade, são jovens, duas moças e um rapaz.

As demais pessoas que afirmaram ter a língua Akwẽ como primeira língua, são crianças, jovens e adultos, dessas, 10 moram na cidade e 180 nas Aldeias. Quanto às que moram na cidade, perguntei se usam a língua Akwẽ em seu cotidiano, elas afirmaram que sim e que só usam o português para se comunicar com os não indígenas. 
Perguntei por que eles optaram por morar na cidade. Dois disseram que estão fazendo curso técnico em Miracema, e um está cursando Pedagogia, e os demais afirmaram que tem filhos em período de escolarização fundamental e média e trouxeram-nos para estudar na cidade, pois acreditam que a educação da cidade é melhor que da Aldeia.

Respeitei o ponto de vista dos que disseram que a educação da cidade é melhor que da Aldeia, porém, ao refletir, pude perceber que isso ainda é reflexo do processo de colonização que fomos submetidos ao longo dos anos. Nesse processo, os indígenas acabam acreditando que o que vem do seu entorno é mais importante que seu próprio conhecimento, e no tocante à educação, acreditam que a educação escolar ofertada nas escolas dos não indígenas é melhor que a educação construída nas escolas das aldeias. Isso porque muitos acreditam que não é necessário estudar a cultura, a língua e os assuntos relacionados aos nossos conhecimentos e que o importante mesmo é português, matemática e outras disciplinas que são cobradas em vestibulares, concursos e outras provas.

Segundo Munduruku (2002), essa é a lógica do dominador, que "desvalorizou as outras formas de leitura e de escrita do mundo e impôs seus olhares e métodos científicos fazendo-nos crêr que sua escrita era mais perfeita que aquela infinitamente mais antiga" (Munduruku Apud Nascimento, 2012, p.52).

Nessa ótica, acabam desvalorizando a educação escolar indígena, um direito conquistado por nós que visa não somente a preparação do aluno para o mercado de trabalho, mas também a afirmação das identidades étnicas, recuperação das memórias históricas, valorização das línguas e conhecimentos dos povos indígenas, além da importante associação entre escola/sociedade/ identidade.

Sobre as línguas usadas dentro da casa, no diálogo com os pais, formulei o seguinte questionamento: Em que língua seus pais falam com você?

Só coloquei como opção a língua portuguesa e a língua Akwẽ, que é o foco de minha pesquisa, apesar de Waikazate e Sirnãwẽ afirmarem que há outras línguas usadas nesses contextos.

Observemos, então, abaixo a representação gráfica dos resultados obtidos para esta pergunta, no Gráfico 11: 
Gráfico 11 - Língua usada em diálogo com os pais.

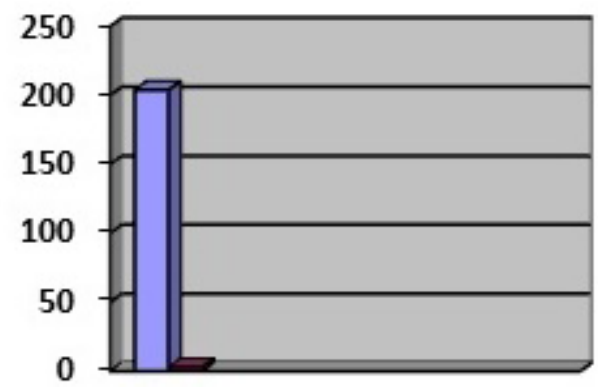

口AKWE

口PORTUGUÊS

Fonte: Sílvia Letícia G. S. Xerente.

De acordo com os dados, podemos observar que a maioria das pessoas se comunica com pais na língua Akwẽ, assim também é feito com os anciãos, pajés, o cacique, o conselheiro e as demais lideranças da aldeia. Segundo Wdêkruwẽ (2012), quando se dirige a fala a essas pessoas mencionadas acima, é preciso atentar para as formas de tratamento e de respeito, repassadas pelos nossos pais e avós.

Podemos, então, observar que a língua Akwẽ possui um local de destaque quando o assunto é família, pois o maior número dos participantes afirmou usar a língua materna no ambiente familiar com os pais.

Quanto aos que afirmaram que usam as duas línguas, são jovens que dizem que sabem a língua Akwẽ, porém como têm o contato maior com o português, principalmente no processo de escolarização, acabam trazendo para o contexto familiar, o que muitas vezes, segundo eles, desagradam os pais.

Nessa mesma linha de pensamento, Silva (2014), afirma que:

a língua akwē prevalece como a língua da interação no ambiente familiar informal da casa, sendo, portanto, a língua mais falada e ouvida pelos jovens. No entanto, no que diz respeito às funções mais formais do uso linguístico, voltadas às atividades de escolarização, como as tarefas de leitura e escrita, o português é a língua predominante. (SILVA, 2014, p. 65) 
Para essa autora, o uso da língua Akwẽ, no ambiente familiar, é de suma importância para garantir a sua sobrevivência. Concordo com a mesma, pois as políticas linguísticas mais eficazes precisam ter início dentro de nossas casas para, então, partirmos para um contexto mais amplo.

Dando continuidade à pesquisa, questionei aos entrevistados: qual língua você mais usa no seu cotidiano?

Gráfico12 - Língua mais usada no cotidiano.

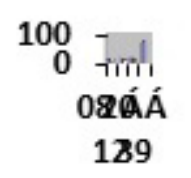

Fonte: Sílvia Letícia G. S. Xerente.

Nesse gráfico, podemos observar que o português está presente, principalmente, no cotidiano dos mais jovens. Questionei, então, em que momentos mais usavam. Segundo eles, na escola; uns estudam em escolas indígenas, outros não. Outros afirmaram que usam quando estão nas redes sociais, ouvindo músicas, jogando futebol, nas festas que não são tradicionais do povo Akwẽ, dentre outros.

O português também é usado, conforme o relato deles, em reuniões da saúde, educação, para a reivindicação de direitos, elaboração de documentos para as autoridades não indígenas, em busca do atendimento das demandas de cada aldeia e nas relações comerciais.

$\mathrm{Na}$ maioria dos casos, o uso da língua portuguesa está relacionado ao contato com o não indígena, ou com povos indígenas de outras etnias, conforme foi mencionado acima. Em apenas alguns casos haverá o uso da língua portuguesa entre falantes de Akwẽ, e quando isso acontece, essa atitude é avaliada de forma negativa pelos demais Akwẽ, segundo afirma Silva (2014): 
dessa forma, não importava em que local ocorresse a interação, ou em que situação de formalidade ou informalidade se viam os participantes, se o interlocutor fosse xerente a língua escolhida seria o xerente. $\mathrm{O}$ português somente seria usado com o interlocutor não-indígena, monolíngue em português, ou em casos de outras etnias que também não fossem falantes de xerente.(...)quando questionados se conheciam alguém que conversasse em português com outro Akwẽ, a resposta era quase sempre afirmativa e o que se seguia era uma avaliação negativa dessa terceira pessoa, como se ela estivesse fazendo algo "errado" (SILVA, 2014, p. 108).

Cabe aqui ressaltar que mesmo em reuniões com a presença de não indígenas, sempre as lideranças fazem o seu discurso em Akwẽ e nem sempre traduzem o que estão falando, isso demonstra que estão em pleno usufruto de seus direitos linguísticos, mesmo sem perceber isso. O uso da língua portuguesa é mais restrito, mesmo nesses ambientes, o que demonstra também a resistência do povo Xerente.

Dando continuidade, perguntei se tem assuntos que só podem ser tratados em português. Vejamos no gráfico 13, abaixo, a representação das respostas:

Gráfico13 - Há assuntos tratados somente em português?
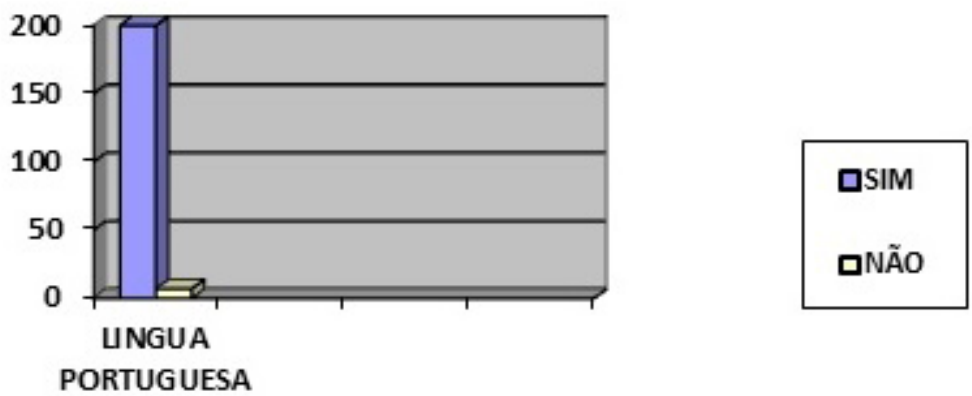

Fonte: Sílvia Letícia G. S. Xerente.

Questionei, então, que assuntos são esses, já que tanta gente respondeu que sim. Os entrevistados relataram que são os seguintes 
que vêm complementar as afirmações da questão anterior: reuniões, assuntos na sala de aula, futebol, política etc. Porém, segundo K.X., "mesmo tendo assuntos que é necessário usar a língua portuguesa, os Akwẽ já estão dando o jeito de traduzir e falar nossa própria língua" (K. X., Aldeia Zé Brito).

Esses assuntos que são trazidos da sociedade envolvente para dentro das nossas comunidades, trazem consigo essa "necessidade" do uso da língua portuguesa, e em alguns casos esse uso pode ser positivo ou negativo, mas disso trataremos mais a frente.

Questionei se esse uso de português poderia acarretar em mudanças da língua Akwẽ. Então, relataram que isso pode acarretar mudanças na cultura, pois ela está diretamente ligada à língua. Segundo alguns entrevistados, essa mudança já é percebida, pois já são usadas palavras da língua portuguesa, mesmo tendo essa palavra em Akwẽ. Segundo eles, também há uma mudança de comportamento, conforme afirma S. X. "Alguns índios se influenciam muito rápido, começam a se exibir por aí, falando na língua portuguesa e deixando de lado a própria língua” (S. X., Aldeia Brupré).

Essa mudança, conforme um entrevistado, traz descontentamento aos pais e aos avós, pois a mudança linguística também é mudança cultural, segundo ele.

Essas análises feitas pelos entrevistados são muito importantes, pois eles demonstram saber as consequências que o uso desordenado pode trazer para o nosso povo.

\section{O contato entre os falantes de português e os falantes}

\section{Akwẽ, ameaça ou enriquecimento linguístico?}

Após analisar os dados, e ler vários autores que abordam as temáticas contato linguístico, mudanças e ameaças linguísticas, pretendo nesse capítulo, retomar a questão que motivou essa pesquisa e dizer se esse contato enriquece ou serve de ameaça para a nossa língua.

Durante a pesquisa, observei que a faixa etária que mais usa a língua portuguesa no seu dia a dia é a de jovens, motivados por vários fatores, como a ida à escola, a aquisição de recursos tecnológicos, o contato com não indígenas que trabalham nas aldeias, dentre outros.

Porém, observamos que esses jovens, mesmo usando essa língua, têm um respeito imenso pela sua língua materna. 
Já as crianças estão tendo o contato bem mais cedo com a língua portuguesa, em comparação às crianças da geração passada. Isso porque com a chegada da energia elétrica nas aldeias, os pais adquiriram a televisão, e assim mesmo sem sair de casa eles já têm o acesso a essa língua.

Os anciãos ainda se mantêm conservadores e guardiões dos nossos conhecimentos tradicionais, e cobram muito dos mais jovens que valorizem essa cultura que é muito importante para todo povo Akwẽ. Quando se fala em contato linguístico, podemos dizer que quando há línguas em contato, há também culturas que entram em contato, portanto devem-se ver os pontos positivos e negativos desse contato.

A língua portuguesa pode ser considerada como enriquecimento linguístico quando é usada em contextos que se exige essa língua, conforme vimos durante a pesquisa, que são nas reivindicações inerentes a melhoria da educação, saúde, qualidade de vida da população Akwẽ.

Entretanto, ela serve de ameaça para a língua Akwẽ, quando passa a ocupar os espaços de uso desta língua. Quando as pessoas passam a usar o português nas aldeias, substituindo palavras que já existem na nossa língua, por exemplo.

Sabemos que o contato entre falantes de línguas diferentes traz mudanças para as línguas. Quando se fala de uma língua indígena em contato com o português, a chance da língua indígena sair na desvantagem é quase inevitável. Porém não é impossível mantê-la, ainda mais quando o povo tem respeito por sua língua.

No caso do povo Akwẽ, pude ver que temos um grande apresso pela nossa língua, o que ajuda na preservação da mesma, pois um povo que gosta de sua língua não quer deixá-la morrer.

Assim, concluo que o contato entre falantes da língua Akwẽ e da língua portuguesa é viável, porém pode servir de ameaça ou enriquecimento, depende da forma como os falantes lidam com essa situação.

Para nós, apesar da língua portuguesa estar presente em algumas de nossas aldeias, ela não está enfraquecendo a nossa língua, porque nós ainda estamos preservando os nossos conhecimentos tradicionais, e passando de geração a geração. 


\section{Considerações finais}

Todos os povos indígenas do Brasil vivem, hoje, em um processo diferente do que os seus antepassados viveram antes da chegada dos europeus. Em particular, os Xerente, um povo resistente ainda, vive nesse processo de transformação.

Muitas influências negativas vêm afetando gradativamente a língua, as tradições, a cultura e o seu modo particular de transmissão e construção de conhecimentos. As tecnologias como celular, televisão, bem como os livros das escolas indígenas em grande parte monolíngues em português, vêm afetando a língua Xerente.

Todos esses produtos, se usados de forma errada, podem possibilitar o esquecimento e a desvalorização dos conhecimentos milenares do povo Xerente.

Destaca-se que crianças e jovens Xerente estão nas escolas, o que inviabiliza muitas vezes o contato com os anciãos para adquirir conhecimentos tradicionais do nosso povo, uma vez que a maioria das escolas indígenas acompanha o tradicional modelo de educação ocidental que não valoriza esse tipo de conhecimento. Ressalto, aqui, que os professores não podem ser culpados por esse tipo de atitude, pois muitas vezes são obrigados a aceitar essas atitudes lamentáveis impostas pelo sistema de Ensino.

Como observamos durante a pesquisa, a contação de histórias no warã, pátio da aldeia que, para nós, é considerado o espaço de aprendizagens, teve seu uso diminuído com a chegada de televisão, computadores, internet, celulares, escola no modelo ocidental que apresentam recursos diferentes das utilizadas nos processos próprios de ensinamento do povo Xerente.

Com isso, o processo de educação do povo Akwẽ sofreu mudanças, pois no warã, os anciãos eram vistos como os professores de hoje, pois eles ensinavam para os jovens todos os conhecimentos necessários para a vida na comunidade e nos contextos interculturais. De lá saia o jovem preparado para ser o bom respeitador, caçador, pescador, arqueiro, dentre outras habilidades. Essa educação era pautada em valores culturais, o que difere dos modelos existentes hoje.

Apesar de todo esse contexto apresentado acima, os Xerente conservam seus conhecimentos através de transmissão oral. Conforme observamos durante a pesquisa, o povo preserva muito a língua Akwẽ e os conhecimentos que são passados através dela. 
O uso de português é feito sim, em especial, pelos mais jovens, mesmo assim, todos eles têm a consciência de que a valorização de sua língua materna se faz necessário para a manutenção dos saberes tradicionais.

Não condeno, aqui, o uso do português, porém acredito que ele deve ser usado de forma sábia para reivindicar nossos direitos, buscar melhorias para as nossas aldeias, nos ajudar nos estudos na universidade, pois assim podemos contribuir com o povo.

Os anciãos também defendem essa ideia, e sempre orientam os jovens para que os mesmos não deixem que o português sufoque a nossa língua materna, mas que seja usado com cautela.

A hipótese levantada por mim no início da pesquisa de que o português estava sendo mais valorizado do que nossa própria língua foi negada, em todos os casos em que estive em pesquisa com os falantes de Akwẽ, eles demonstraram muito respeito pela língua materna e pelos conhecimentos tradicionais. Isso prova que, mesmo em contato com falantes de língua portuguesa, os Akwẽ são muito resistentes e não abrem mão dos seus conhecimentos repassados de geração a geração.

As transformações na cultura e em aspectos linguísticos não podem ser consideradas como aspecto negativo para nós, pois a cultura é dinâmica e vai mudando com o passar dos anos, mas devemos ficar sempre atentos à valorização e à preservação da nossa língua materna, cultura e os conhecimentos tradicionais.

\section{Referências bibliográficas}

Braggio, Silvia L. B. A aquisição do português escrito pela criança xerente akwén: aspectos cognitivos, sociolinguísticos e educacionais. Anais Internacionais do IV SIMELP, 1764-1777. Goiânia: UFG, 2014.

Braggio, Silvia L. B. Os diferentes tipos de situação sociolingüística e os tipos de empréstimo na adição do português ao xerente akwén: fatores positivos e negativos. LIAMES 12: 157-177. 2012.

BRASIL, 1989. Constituição (1988). Constituição da República Federativa do Brasil, promulgada em 5 de outubro de 1988. Brasília: Senado Federal.

Cadernos de Letras da UFF - Dossiê: Letras, linguística e suas interfaces n40, p. 239-247, 2010. 
CARVALHO, Isabel Cristina de Oliveira. Educação ambiental: a formação do sujeito ecológico. $4^{\mathrm{a}}$ ed. São Paulo: Cortez, 2008.

DE PAULA, Luís Roberto. A dinâmica faccional Xerente: esfera local e processos sociopolíticos nacionais e internacionais. Dissertação de Mestrado. USP: São Paulo, 1999.

FILHO, Sinval Martins de Sousa. Aquisição do Português Oral pela criança Xerente. Dissertação de Mestrado. Goiânia: UFG, 2000.

FRANTOMÉ, Pacheco. O ikpeng em contato com o português: empréstimo lexical e adaptação linguística.

FREIRE, P. A importância do ato de ler. In Col. Polêmicas do Nosso tempo. São Paulo: Editora Cortez, 1985.

GIRALDIN, Odair. Educação indígena na área xerente, apropriação e reforço cultural. In Cidadania, interculturalidade e formação de docentes indígenas. ROCHA, Leandro Mendes; SILVA, Maria do Socorro Pimentel. BORGES, Mônica Veloso (Orgs). Goiânia: Editora da PUC Goiás, 2010.

MARTINY, Franciele Maria; MENONCIN, Camila. O estudo do bilinguismo e da diglossia para uma perspectiva linguística educativa. In: Web-Revista SOCIODIALETO: Bach., Lic., Mestrado - Letras - UEMS/Campo Grande, v. 4, n. 11, nov. 2013.

MELO, Elisângela Aparecida Pereira. Investigação etnomatemática em contextos indígenas: caminhos para a reorientação da prática pedagógica. Natal, RN, 2007.

MORI, Angel Corbera. Aspectos de la morfología nominal Aguaruna (Jíbaro). Hein van der Voort \& Simon van de Kerke (eds.), Indigenous Languages of Lowland South America [Indigenous Languages of Latin America, 1], p. 213-223. Leiden: Research School of Asian, African, and Amerindian Studies (CNWS), 2000.

MUNDURUKU, Daniel. A escrita e a autoria fortalecendo a identidade. In: RICARDO B.; RICARDO, F.(orgs.). Povos indígenas no Brasil: 2001-2005. São Paulo: Instituto Socioambiental, 2006. p. 200-202.

NASCIMENTO, André Marques do. Português intercultural: atividades e reflexões sobre a língua de relações interculturais dos povos indígenas brasileiros. Goiânia: FUNAPE/PROLIND, 2012.

NIMUENDAJÚ, Curt. The Xerente. Los Angeles: L. A. Press, 1942. 
RODRIGUES, Aryon. Línguas brasileiras: para o conhecimento das línguas indígenas. São Paulo. Edições Loyola, 2002.

RODRIGUES, Aryon Dall'lagna. Sobre as línguas indígenas e sua pesquisa no Brasil. 2005.

SCHROEDER, Ivo. Política e parentesco nos Xerente. Tese de doutorado. USP: São Paulo, 2006.

SILVA, Joana Aparecida Fernandes. Educação indígena na área Xerente, apropriação e reforço cultural. In Cidadania, interculturalidade e formação de docentes indigenas. ROCHA, Leandro Mendes; PIMENTEL DA SILVA, Maria do Socorro; BORGES, Mônica Veloso. Goiânia: Ed. da PUC Goiás, 2010.

SILVA, Júlia Isabelle da. Entre conflitos e resistências: Usos e atitudes linguísticas de jovens Akwẽ-Xerente, Dissertação de Mestrado. Goiânia: UFG, 2014.

XERENTE, Rogério Srõne. O consumo de alimentos industrializados entre os Akwe, 2013. Trabalho de Conclusão de Curso (Graduação em Educação Intercultural - Ciências da Natureza). Goiânia: UFG, 2013.

XERENTE, Sinval Waikazate de Brito. Estudo de palavras e variações sonoras na língua Akwe-Xerente: as falas dos velhos e dos mais jovens. Trabalho de Conclusão de Curso (Graduação em Licenciatura Intercultural). Goiânia: UFG, 2012.

XERENTE, Sinval Waikazate de Brito; XERENTE, Silvino Sirnãwe. Proposta de Projeto Político Pedagógico para as escolas do povo Akwẽ. Monografia de Especialização em Educação Intercultural: Gestão Pedagógica. Goiânia: UFG, 2014.

XERENTE, Valteir Tpêkru. Discurso dos Velhos Akwẽ Xerente. Romkrêptkã. Trabalho de Conclusão de Curso (Graduação em Licenciatura Intercultural). Goiânia: UFG, 2011.

WEWERING, Sillvia Thêla (org.). Povo Xerente: Vida, Cultura e Identidade. $1^{\text {a }}$ Ed. Belo Horizonte, 2012. 